\title{
DINAMIKA POLITIK ISLAM SEMENANJUNG ARAB 1800-1930 M DAN PENGARUH BERDIRINYA KERAJAAN ARAB SAUDI MODERN TERHADAP PRAKTIK KEAGAMAAN
}

\author{
Ihwan Agustono \\ Sekolah Tinggi Ilmu Ushuluddin al-Mujtama' Pamekasan, Indonesia \\ E-mail: ihwan_agus@yahoo.com
}

\begin{abstract}
The article examines the dynamics of political Islam of the Arabian Peninsula in 1800-1930 and their influence to the foundation of the Modern Saudi Arabia Kingdom and their impact to religious practices in the Holy Land. The study is considered important due to the changing phenomenon of religious understanding in the Holy Land. A new orthodox ideology has been able to change the well-established traditional understanding and become a dominant school until nowadays. The study concludes that: 1) Socio-political constellation of Hijaz before 19th century had been marked by the decrease of political supremacy of Hijaz along with far migration of the Islamic governmental center from Madinah; 2) One of the culminations of political dynamics of the Arabian Peninsula between 1800 and 1930 was the establishment of the Modern Saudi Arabia Kingdom; 3) Such political dynamics have subsequently resulted in the purification of Islamic sharî́ah in accordance with the Wahabi's doctrines, obliteration of the tradition of four maqâmât in Masjid al-Ḥarâm, conformation of Islamic education with the Wahabi's dogmas, and the increase of orthodoxy and the decrease of popular Sufi's credo.
\end{abstract}

Keywords: Political dynamics; the Arabian Peninsula; the Modern Saudi Arabia Kingdom; religious practices.

\section{Pendahuluan}

Hijaz adalah negeri kelahiran Islam dan sering disebut sebagai pusat keagamaan Islam. Dua kota suci umat Islam yang sangat terkenal dan 
bersejarah, yaitu Mekah dan Madinah, juga terletak di sana. ${ }^{1}$ Mekah sendiri adalah kota kelahiran Nabi Muhammad dan kota tempat Nabi pertama kali menerima wahyu dan mendakwahkan ajaran-ajaran agama Islam. Di kota ini terletak Ka‘bah, kiblat salat umat Islam. Di kota ini pula umat Islam datang setiap tahun untuk menunaikan ibadah haji, rukun Islam yang kelima. ${ }^{2}$

Mayoritas para haji sebelum atau sesudah menunaikan ibadah haji hampir dapat dipastikan akan mengunjungi kota Madinah untuk tujuan ziarah, karena di sana terdapat makam Nabi Muhammad dan tempattempat bersejarah dalam perkembangan awal Islam. Madinah adalah kota tempat negara Islam pertama berdiri dan dari sanalah perluasan Islam bermula. ${ }^{3}$ Sejak berdirinya negara Islam hingga berakhirnya pemerintahan al-Khulafâ' al-Râshidûn, kota Mekah dan Madinah menjadi pusat politik dan rohani Islam sekaligus. ${ }^{4}$

Setelah berpindahnya kekuasaan politik dari al-Khulafâ' al-Râshidûn ke tangan Bani 'Umayyah, negeri ini tidak pernah lagi menjadi pusat kekuasaan politik Islam. Semenjak itu, Hijaz secara berangsur-angsur tenggelam dan tidak memainkan peran signifikan lagi dalam sejarah. Bersamaan dengan penaklukan-penaklukan yang dilakukan oleh kaum Muslim awal, banyak penduduk Jazirah Arab, terutama Hijaz, melakukan imigrasi dan menetap di daerah-daerah yang baru ditaklukan. ${ }^{5}$

Setelah penaklukan-penaklukan gemilang yang menandai awal suatu zaman baru dalam peradaban Timur Tengah itu bangsa Arab justru membiarkan Arabia mengeluarkan banyak penduduknya. Sejak saat itu Jazirah Arab, termasuk di dalamnya Hijaz, berdiri di luar mainstream perkembangan Timur Tengah. ${ }^{6}$ Bahkan, setelah kejayaan Dinasti 'Abbâsîyah runtuh, kekuatan politik bangsa Arab, pembawa kebangkitan

1 Hijaz adalah satu dari lima area di Jazirah Arab. Empat area lainnya adalah Yaman, Tihamah, Nejd, dan Arud. Muḥammad Bayyûmî Mahrân, Dirâsât fî̀ Târikh al-'Arab alQadîm (Riyad: al-Matâbi‘ al-Ahlìyah, 1997), 98.

2 Richard C. Martin, Pendekatan Kajian Islam dalam Studi Agama, terj. Zakiyuddin Baidhawy (Surakarta: Muhammadiyah University Press, 2002), 112.

3 Azyumardi Azra, Jaringan Ulama Timur Tengah dan Kepulauan Nusantara Abad XVII dan XVIII (Jakarta: Prenada Media, 2004), 52.

4 Yayan Sopyan, Tarikh Tasyri': Sejarah Pembentukan Hukum Islam (Depok: Gramata Publishing, 2010), 56.

${ }^{5}$ Fazlur Rahman, Major Themes of the Qur'an (Chicago: Bibliotheca Islamica, 1980), 92.

6 Ira M. Lapidus, A History of Islamic Societies (Cambridge: Cambridge University, 1989), 668. 
Islam pertama itu dengan cepat merosot dan nampak terlupakan. ${ }^{7}$ Hampir seluruh wilayah Arab, sejak itu, berada di bawah kekuasaan politik non-Arab.

Setelah Imperium Turki 'Uthmânî menguasai negeri-negeri Arab di awal abad ke-16 M, Mesir dan Jazirah Arab berubah menjadi propinsipropinsi bagian dari Imperium 'Uthmânî. Hal yang demikian berlangsung sampai awal abad ke-20 M. Namun di beberapa wilayah pinggiran kekuatan politik bangsa Arab masih bertahan, tetapi hanya dalam batasbatas wilayah yang sempit, bahkan di antaranya hanya dalam bentuk keamiran (al-imârah). ${ }^{8}$

Hijaz sendiri-semenjak munculnya dinasti-dinasti kecil dalam sejarah Islam—hampir selalu berada di bawah pengaruh politik dinasti yang berkuasa di Mesir. Ketika Imperium Turki 'Uthmânî mengusai negeri-negeri Arab, Mesir menjadi salah satu propinsinya. Ketika itu, penguasa Hijaz merasa bahwa Turki 'Uthmânî adalah pewaris kepemimpinan Islam, dan dipandang sebagai penjaga agama dan pengibar bendera jihad melawan orang kafir. Oleh karena itu, Shariff Mekah-sebutan untuk penguasa Hijaz-tidak merasa keberatan menyerahkan kunci Ka'bah kepada Sultan 'Uthmânî, Salîm I, sebagai bukti bahwa mereka sedia menyerahkan kepemimpinan Hijaz kepada Turki 'Uthmânî tidak lama setelah Sultan berhasil mengalahkan Dinasti Mamâlik dan mengusai Mesir pada 1517 M. Sebagaimana sebelumnya, pada masa pendudukan Turki 'Uthmânî ini Hijaz mula-mula merupakan bagian dari wilayah (propinsi) Mesir itu. ${ }^{9}$

Pada masa-masa tersebut, di Jazirah Arab terjalin relasi yang cukup mesra antara penguasa (Shariff) Mekah dengan Istanbul Turki yang akhirnya menjadi rusak dengan bangkitnya gerakan keagamaan di Semenanjung Arab yang didirikan oleh Muhammad b. 'Abd al-Wahhâb. Gerakan ini di kenal dengan gerakan Wahabi. ${ }^{10}$ Gerakan ini selanjutnya

\footnotetext{
${ }^{7}$ Aḥmad al-Sibâîi, Târîkh Mekah, Vol. 1 (Mekah: Maktabah al-Ṣafâ, 1420), 5.

8 Abdul Chalik, Islam dan Kekuasaan: Dinamika Politik dan Perebutan dalam Ruang Negara (Yogyakarta: Interpena, 2012), 80.

${ }^{9}$ Badri Yatim, Sejarah Sosial Keagamaan Tanah Suci: Hijaz (Mekah dan Madinab) 1800-1925 (Jakarta: Logos Wacana Ilmu, 1999), 3.

10 Fabe Armanions, "The Islamic Traditions of Wahhabism and Salafiyya”, dalam CRS Report for Congress, mmm.fas.org/sgp/crs/misc/RS21695.pdf. (20 Maret 2013), 1.
} 
memiliki pengaruh yang besar terhadap pranata sosial Islam di Indonesia, khususnya pada akhir zaman penjajahan Belanda. ${ }^{11}$

Ketika mencapai kekuatan politik dan militer, gerakan ini secara sistematis menghancurkan segala sesuatu yang dipandang penyebab berkembangnya ajaran-ajaran bid'ah dalam Islam. Ibn 'Abd al-Wahhâb dilindungi oleh penguasa Nejd, Muhammad b. Sa'ûd yang berkedudukan di Dar'îyah. Antusiasme ide purifikasi menjadi kekuatan yang menentukan di balik ekspansi politik keluarga Saudi. Di akhir abad ke-18 M, seluruh Nejd sudah dapat mereka duduki, bahkan Irak sudah pula mereka serang. Kota-kota suci di Hijaz mereka kuasai dan mereka bersihkan dari praktik-praktik yang dipandang bertentangan dengan paham yang mereka anut. ${ }^{12}$

Sejak bangkitnya gerakan Wahabi yang bersekutu dengan keluarga Saudi itu, Jazirah Arab, terutama daerah Hijaz, menjadi ajang perebutan pengaruh yang melibatkan banyak pihak. Secara alamiah penguasa Turki 'Uthmânî terdorong untuk melakukan suatu reaksi, dan Sultan memerintahkan gubernur Mesir, Muhammad Ali Pasha, untuk menghadapi orang-orang Wahabi. Pada tahun 1818 Muhammad Ibrâhîm Pasha, putra dari Muhammad Ali Pasha berhasil menaklukkan Dar'îyah pusat gerakan Wahabi ketika itu, dan juga menduduki Hijaz. Orangorang Turki kemudian didatangkan ke Hijaz untuk mengamankan kepentingan politik kerajaan Turki 'Uthmânî di sana. Sementara di Nejd, Turki 'Uthmânî mendukung penguasa lokal, keluarga Rashîdîyah, yang menjadi musuh keluarga Saudi. Namun, justru setelah itu, Muhammad Ali Pasha, gubernur Mesir, merasa besar dan siap bersaing melawan Sultan Turki 'Uthmânî di Istanbul. ${ }^{13}$

11 Ali Mufrodi, Pranata Sosial Islam di Indonesia 1900-1942: Politik dan Pendidikan (Surabaya: Alpha, 2007), 98; Musyrifah Sunanto, Sejarah Peradaban Islam Indonesia (Jakarta: Raja Grafindo Persada, 2012), 133.

12 Dalam ajarannya, kelompok ini tidak segan-segan melakukan takfîr kepada siapa saja yang telah melanggar sepuluh pembatal Islam, yang salah satunya adalah hukum kafir terhadap individu atau kelompok yang membiarkan, ragu atau membenarkan kesalahan aqidah yang dilakuakan oleh orang Islam yang telah melanggar sepuluh pembatal Islam yang telah mereka susun ini. Muhammad b. 'Abd al-Wahhâb, Nawâqid al-Islâm dalam Matan al-Taubîd wa al-'Aqîdah (Mekkah: Dâr Ibn 'Umar, 2003), 159.

13 Philip K. Hitti, History of The Arabs: From the Earliest Times to the Present, terj. Cecep Lukman Yasin, dkk. (Jakarta: Serambi Ilmu, 2010), 927. 
Pada saat Perang Dunia I mulai berkobar, banyak pemimpin Arab mulai ragu-ragu terhadap masa depan negerinya bila tetap berada dibawah kontrol Turki 'Uthmânî. Mengetahui hal itu, pada tahun 1916 M seorang komisaris tinggi Inggris yang berkedudukan di Kairo, Mesir berhasil membujuk Sharif Mekah, kepala keluarga Arab yang menguasai kota-kota suci sebagai wakil Sultan, untuk bersekutu dengan Inggris yang menjanjikan kemerdekaan Arab, dalam melawan orang-orang Turki 'Uthmânî di Hijaz. Sharîf Mekah yang kemudian dikenal dengan Raja Husayn ini menyambut ajakan itu dan bertekad untuk mewujudkan negara Arab bersatu di Asia dengan Mekah sebagai pusatnya. Dia kemudian mengirim anaknya yang bernama Faisal untuk menjadi penguasa ke Suriah pada tahun 1918 M dan berhasil mendirikan pemerintahannya di Damaskus, sementara anaknya yang lain, Abdullah, juga dikirim ke Irak. ${ }^{14}$

Akan tetapi, setelah wilayah Arab di Asia dibagi-bagi kepada Inggris (Irak dan Palestina) dan Perancis (Suriah dan Libanon) pada tahun 1920 M, cita-cita negara Arab bersatu itu mulai mengendur. Kalau sebelumnya Raja Husayn dipandang sebagai Raja Arab, setelah itu dia hanya diakui sebagai penguasa Hijaz. Ambisi Raja Husayn itu betul-betul sirna setelah 'Abd al-Azîz b. Sa'ûd, pimpinan gerakan Wahabi asal Nejd, pada tahun 1924 M mengadakan serangan serius terhadap Hijaz. Serangan itu mengakhiri kekuasaan Raja Husayn di sana, dan dia sendiri akhirnya melarikan diri ke Amman, Yordania. 'Abd al-Azîz b. Sa'ûd kemudian menobatkan dirinya sebagai Raja Hijaz dan Nejd, Raja yang sungguhsungguh menguasai sebagian besar Jazirah Arab. Inilah tonggak awal kemunculan negara Arab Saudi modern yang masih tetap eksis sampai saat ini. ${ }^{15}$

Memang banyak kesamaan antara perkembangan satu daerah Arab dengan daerah Arab lainnya pada tahun 1800 M sampai 1925 M. Hampir seluruhnya mengadakan pemberontakan terhadap kekuasaan Turki 'Uthmânî dan hampir seluruhnya pula dapat dipadamkan, meskipun akhirnya jatuh ke dalarn kekuasaan Barat. ${ }^{16}$ Namun, perkembangan yang

\footnotetext{
14 Yatim, Sejarah Sosial, 4.

15 Abdullah Mohammad Sindi, "Britain and the Rise of Wahhabism and the House of Saud”, dalam Kana'an Bulletin, www.kanaanonline.org (20 Maret 2013), 2.

16 Sukran Kamil, Pemikiran Islam Tematik: Agama dan Negara, Demokrasi, Civil Society, Syariah dan HAM, Fundamentalisme, dan Antikorupsi (Jakarta: Kencana, 2013), 56.
} 
terjadi di Jazirah Arab, terutama di Hijaz dapat dikatakan unik. Di sini pergolakan politik yang terpenting, gerakan Dinasti Saudi, berkaitan sangat erat dengan munculnya satu gerakan reformis yang mendahuluinya yang dikenal dengan gerakan Wahabi. Bahkan dalam perkembangan selanjutnya keduanya tidak dapat dipisahkan. ${ }^{17}$

Dengan demikian, pergolakan politik di Jazirah Arab, termasuk Hijaz, di samping rnerupakan perebutan kekuasaan, juga dikatakan sebagai gambaran persaingan antara paham keagamaan lama dengan paham yang baru. Ulama dan lembaga-lembaga keagamaan lama tidak bersedia menanggung risiko kehilangan pengaruh bila Dinasti Saudi memperoleh kemenangan. Dalam perebutan kekuasaan itu akhirnya Dinasti Saudi yang menganut paham Wahabi memang memperoleh kemenangan dan bahkan menetapkan paham itu sebagai paham negara. ${ }^{18}$

Kemenangan politik Dinasti Su'ûd ini adalah juga hasil dari keberhasilan gerakan dakwahnya. Oleh karena itu, bukan tidak mungkin perubahan-perubahan sosial-keagamaan sudah terjadi sebelum atau menjelang kemenangan politiknya tersebut. Kernungkinan hal itu didukung oleh kenyataan bahwa ketika Ibn Sa'ûd berhasil menduduki kota-kota suci Islam di Hijaz dengan mengalahkan Raja Ḥusayn, ia langsung menjadi pemimpin yang sangat dihormati di Jazirah Arab bahkan di seluruh Dunia Arab. ${ }^{19}$

Hal yang menarik lainnya adalah bahwa perubahan paham keagamaan itu berlangsung di dua kota suci Islam yang merupakan pusat studi tradisional keagamaan Islam sejak berabad-abad. Paham yang sudah lama mengakar di sana dan kemudian juga menyebar ke segala penjuru dunia Islam, dalam waktu yang dapat dikatakan tidak terlalu lama, harus menerima kehadiran paham baru yang justru menjadi lebih dominan. Oleh karena itu, sangat menarik untuk mengetahui proses perubahan itu sebenamya.

Perubahan-pembahan politik dan paham keagamaan di Semenanjung Arab yang dimotori oleh pengikut Ibn 'Abd al-Wahhâb dan Bani Su'ûd dengan gerakan Wahabi-nya tentu saja mendatangkan perubahanperubahan dalam bidang-bidang sosial-budaya lainnya. Apalagi awal abad

17 Ahmad Dallal, "The Origins and Objectives of Islamic Revivalist Thought (17501850)", Journal of the American Oriental Society, Vol. 113. No. 3 (Juli-September 1993), 342. ${ }^{18}$ Hitti, History, 948.

${ }^{19}$ Mukti Ali, Alam Pikiran Islam Modern di Timur Tengah (Jakarta: Djambatan, 1995), 43. 
ke-19 M merupakan masa ketika gerakan pembaruan dalam Islam baru mulai bangkit. Gerakan pembaruan dalam Islam itu tentu saja juga membawa dampak tertentu pada kehidupan sosial keagamaan Islam di Hijaz, bahkan juga di seluruh penjuru dunia Islam termasuk Indonesia sampai saat ini. ${ }^{20}$

Secara umum, "kertas kerja" ini mencoba menganalisis keadaan sosial politik dan sosial keagamaan di Hijaz sebelum abad ke-19 serta apa saja perubahan politik yang terjadi di Semenanjung Arab antara tahun 1800 sampai dengan $1930 \mathrm{M}$ dan apa pengaruh yang terjadi dalam aspek sosial keagamaan dengan berdirinya Kerajaan Arab Saudi Modern?

\section{Kerajaan Arab Saudi Modern dan Kontribusi Muhammad b. 'Abd al-Wahhâb}

Secara historis, ide purifikasi tauhid yang dipelopori oleh Ibn Taymiyah telah memperoleh dukungan kuat yang dilanjutkan oleh muridnya, Ibn Qayyim al-Jawzîyah (1292-1350 M). Tiga abad setelah itu-disebabkan fakta semakin mundurnya dunia Islam, baik dalam lapangan keagamaan maupun politik dan peradaban, dan pasca-kejatuhan Baghdad dan Andalusia-mendorong gerakan pembaruan fase yang kedua, yaitu pembaruan abad ke-18. ${ }^{21}$

Salah satu gerakan pembaruan terbesaryang lahir pada fase kedua ini adalah gerakan Salafi Wahabi yang dipelopori oleh Muhammad b. 'Abd al-Wahhâb di Nejd. Gerakan ini memiliki pengaruh signifikan terhadap gerakan purifikasi akidah di kerajaan Arab Saudi Modern, baik pada periode pertama maupun pada periode kedua setelah serangan terhadap Hijaz oleh Gubernur Muhammad Ali Pasha di Mesir. Fakta tersebut dilandasi paling tidak karena dua alasan. Pertama, karena gerakan keagamaan Ibn 'Abd al-Wahhâb mempunyai titik tekan pada masalah pemurnian tauhid. Kedua, gerakan ini mendapatkan dukungan penuh,

\footnotetext{
20 Tentang gerakan pembaruan di Indonesia dan hubungannya dengan keadaan politik dan intelektual di tanah Hijaz, lihat Deliar Noer, Gerakan Modern Islam di Indonesia 19001942 (Jakarta: LP3ES, 1980), 38; Azyumardi Azra, Renaisans Islam Asia Tenggara: Sejarah Wacana dan Kekuasaan (Bandung: Remaja Rosdakarya, 2000), 76.

21 Muhamamd Thahir Badrie, Syarah Kitab al-Taubid Muhammad bin Abdul Wahab (Jakarta: Pustaka Panjimas, 1987), xvi.
} 
bahkan tidak dapat dipisahkan dari gerakan politik Dinasti Su'ûd yang menyokong penuh dakwah Wahabi. ${ }^{22}$

Kekuasaan sebagai sarana untuk menyebarkan paham keagamaan memang merupakan sebuah kelaziman dalam tradisi politik Islam. Relasi antara umara (rezim penguasa) dan ulama seperti ini sangat mudah dan sering sekali terjalin karena melaui relasi tersebut, politik dan agama bisa saling mendapatkan keuntungan. Karena itu, kehadiran paham keagamaan (school of thought) seringkali menjadi sumber inspirasi bagi terbentuknya sebuah institusi politik (dinasti), seperti dalam kasus berdirinya Kerajaan Arab Saudi Modern ini. ${ }^{23}$

Ibn 'Abd al-Wahhâb adalah seorang faqîh bermazhab Hanbalî yang belajar agama ke Basrah sekira empat tahun, di Baghdad lima tahun, serta di Kurdistan, Namdan, dan Isfahan. Di kota terakhirini ia belajar filsafat dan tasawuf. Dari perjalanan ilmiahnya, ia melihat kerusakan akidah, seperti meminta tolong kepada shaykh atau wali tarekat, kekuatan gaib, berdoa dengan melalui perantara (tawașsul) dan lain-lain. ${ }^{24}$ Ibn 'Abd alWahhâb berpendapat bahwa umat Islam harus kembali kepada ajaran seperti yang dianut dan diamalkan Rasulullah, sahabat, dan tâbiî̀n. Sumber ajaran hanya al-Qur'ân dan Hadîth, dan untuk memahaminya dipakai metode ijtihad. Upaya dan pemurnian yang dilakukan oleh kelompok ini seringkali disebut dengan gerakan Salafi Wahabi. ${ }^{25}$

Istilah Wahabi sebenarnya adalah penamaan yang disematkan oleh musuh-musuh aliran Ibn 'Abd al-Wahhâb ini. Pengikut Ibn 'Abd alWahhâb sendiri lebih memilih menyebut diri mereka sebagai al-Muslimûn atau al-Muwaḥhidûn, yang berarti pendukung ajaran yang memurnikan ketauhidan kepada Allah. Mereka juga menyebut diri mereka sebagai pengikut mazhab Ḥanbalî atau Abl al-Salaf. Selain itu mereka juga biasa menamakan diri sebagai kaum Sunnî, pengikut mazhab Hanbalî, sebagaimana yang dianut oleh Ibn Taymîyah. ${ }^{26}$

22 Thoha Hamim, Islam dan NU di Bawah Tekanan Problematika Kontemporer: Dialektika Kehidupan Politik, Agama, Pendidikan dan Sosial Masyarakat Muslim (Surabaya: Diantama, 2004), 221-224.

23 Ibid., 222.

${ }^{24}$ Muḥammad b. 'Abd al-Wahhâb, Kashf al-Shubuhât (Mekkah: Dâr Ibn 'Umar, 2003), 49.

25 Sopyan, Tarikh Tasyri', 148.

${ }^{26}$ Hamim, Islam dan NU, 223. 
Pemikiran salafi Ibn 'Abd al-Wahhâb banyak dipengaruhi oleh pemikiran Ibn Taymîyah, ${ }^{27}$ terutama dalam metode penafsirannya yang skripturalis dan menolak unsur-unsur bid'ab dalam sharî'ah Islam. Namun demikian, tak dapat dipungkiri pula bahwa Ibn 'Abd al-Wahhâb memberikan proporsi besar terhadap penggunaan ijtihad dibandingkan taqlîd buta. ${ }^{28}$ Namun gerakan pembaruan yang diwacanakan ini memiliki corak dan warna pemurnian yang lebih keras dari para pendahulunya tersebut. Munculnya gerakan Wahabi memang tidak terlepas dari kondisi umat Islam di wilayah Semenanjung Arab saat itu yang mengalami dekadensi bidang akidah dengan maraknya berbagai praktik yang dianggap telah menyimpang dan mengandung unsur-unsur kemusyrikan, bid'ah, dan takhayul. Fenomena tersebut sebagai akibat dari semakin jauhnya spirit Islam dari sumber ajaran Islam yang asli, yaitu al-Qur'ân dan al-Sunnah. Juga karena pengaruh dari praktik-praktik keagamaan lama yang bangkit kembali. ${ }^{29}$

Berbeda dengan para pendahulunya, Ibn 'Abd al-Wahhâb dan para pengikutnya lebih menekankan pada pemurnian tauhid yang lebih praktis dan terkadang cenderung reaktif. ${ }^{30}$ Dikatakan reaktif karena selain doktrin mereka yang keras, terutama dalam masalah syirik dan Nawâqid al-Islâm, juga karena adanya sokongan penuh dari penguasa Dinasti Su'ûd, di mana dalam sejarah Islam kolaborasi ulama-penguasa seperti ini telah banyak terbukti mampu membuahkan kesuksesan yang luar biasa. Penguasa dari Dinasti Su'ûd inilah yang kemudian menjadi pembela utama kelompok Wahabi dalam menyebarkan doktrin ajarannya. ${ }^{31}$ Berdirinya Kerajaan Arab Saudi Modern pada awal abad ke-20 memiliki pengaruh signifikan terhadap lestarinya ajaran-ajaran Wahabi di Tanah Suci setelah sempat padam oleh serangan gubernur Mesir, Muhammad Ali Pasha pada tahun 1818 M. Dengan dukungan tersebut, Wahabi terus melakukan propaganda masif dalam masalah pemurnian akidah Islam. ${ }^{32}$

Tentang dasar-dasar dari doktrin pemurnian akidah ini, apabila pemikiran Ibn 'Abd al-Wahhâb ditelusuri secara komprehensif, terdapat

\footnotetext{
27 Azra, Jaringan Ulama, 157.

28 Ibid., 313.

${ }^{29}$ Hitti, History, 948.

30 Ibid., xvii.

31 Abû Muhammad 'Âṣim al-Maqdisî, al-Kawâshif al-Jalîyah fî Kufr al-Dawlah al-Su'ûdîyah (Riyad: Muassasat al-Rafid, t.th.), lampiran 1.

32 Ali Mufrodi, Islam di Kawasan Kebudayaan Arab (Surabaya: Anika Bahagia, 2010), 157.
} 
beberapa konsep penting yang berhubungan erat dengan propaganda purifikasi yang diusung, sekaligus menjadi landasan utama bagi kebijakan politik yang mereka usung, antara lain: Pertama, konsep tentang pokokpokok Islam; Kedua, konsep dan batasan syirik; dan Ketiga, konsep tentang Nawâid al-Islâm (hal-hal yang membatalkan iman) yang tentu saja pada praktiknya susah untuk dipisahkan dari masalah takfîr. ${ }^{33}$

Dalam pandangan Ibn 'Abd al-Wahhâb, ada tiga dasar agama yang harus diketahui oleh setiap Muslim agar keislamannya autentik, yaitu: pengetahuan terhadap Allah, pengetahuan tentang agama Islam, dan pengetahuan tentang Nabi Muhammad. Menurutnya, pengetahuan terhadap tiga hal tersebut lebih penting dan harus didahulukan daripada mengamalkannya. Dalam setiap poin, terdapat keterangan dan penjabaran serta rukun-rukunnya yang diperkuat dengan dalil-dalil dari al-Qur'ân dan al-Hadîth. Dalam dasar ini tercantum juga konsep tentang rukun Islam, cabang-cabang iman yang berjumlah sekitar tujuh puluh jenis, dan tidak ketinggalan konsep iḥsân juga terdapat dalam tiga dasar ini. ${ }^{34}$

Secara umum, hampir tidak ada perbedaan antara konsep ini dengan konsep-konsep Islam yang sudah dikenal luas dalam Islam, namun ada satu hal yang menarik yaitu dalam definisi dan kaidah hijrah. Menurutnya, hijrah adalah berpindahnya umat Islam dari negeri syirik menuju kepada negeri Islam, yang dimulai sejak zaman Nabi sampai hari kiamat. ${ }^{35} \mathrm{Hal}$ ini menarik karena ketika Ibn 'Abd al-Wahhâb berbicara tentang orang musyrik dan negara syirik di zaman sekarang seolah-olah predikat tersebut diperuntukkan bagi ulama dan negara-negara Islam selain Arab Saudi. Dengan kata lain, negara manapun yang tidak sesuai dengan ajaran mereka akan disebut dengan tâghut. ${ }^{36}$ Umat Islam yang berada dalam negeri kafir ini-menurut Ibn 'Abd al-Wahhâb_tidak ada pilihan lain kecuali pindah ke negeri Islam serta menaati pemimpin di sana, yaitu pemimpin yang lurus akidahnya. ${ }^{37}$

33 Tentang takfîr lihat Imam Ghazali Said, Pengkafiran Sesama Muslim Menurut Abu Hamid al-Ghazali (Surabaya: Diantama, 2012), 73-77.

${ }^{34}$ Muhammad b. 'Abd al-Wahhâb, Thalâthat al-Ușûl (Mekkah: Dâr Ibn 'Umar, 2003), 5.

35 Ibid., 20.

36 Ibid., 25.

37 Muḥammad b. 'Abd al-Wahhâb, Sittah Uṣ̂ul 'Adhîmah (Mekkah: Dâr Ibn 'Umar, 2003), 78 . 
Menurut Ibn 'Abd al-Wahhâb, peperangan Rasulullah selama berdakwah di Madinah bukan peperangan melawan orang-orang kafir yang tidak beragama, melainkan lebih pada memerangi orang-orang yang sudah mengakui rubûbîyah Allah namun tidak melaksanakan ibadah (syirik) kepada-Nya dengan semestinya. ${ }^{38} \mathrm{Jadi}$, syirik menurut mereka adalah menyekutukan Allah dengan hal-hal lain, dan pelakunya wajib untuk diperangi, sebagaimana yang telah dilakukan oleh Rasulullah dan para sahabatnya. Pelaku syirik yang ada pada zaman sekarang ini dinilai lebih besar dosanya dari pada pelaku syirik yang ada pada zaman Rasulullah. Menurutnya, pelaku bid'ah lebih terlaknat dari pada pelaku dosa besar (kabâir). ${ }^{39}$

Ibn 'Abd al-Wahhâb juga mengajarkan bahwa ada sepuluh hal yang dapat membatalkan keislaman seseorang, atau dengan kata lain menjadikannya sebagai seorang kafir. Apabila seorang Muslim telah melakukan salah satu dari sepuluh hal tersebut, ia tidak lagi dapat dikategorikan seorang Muslim, sehingga otomatis keadaan orang tersebut di antara dua hal yaitu, antara kâfir dhimmî yang tetap harus dijamin kemanannya oleh umat Islam atau kâfir ḥarbî yang wajib untuk diperangi karena halal darahnya. ${ }^{40}$

Nawâqid al-Islâm (hal-hal yang membatalkan iman) yang pertama adalah syirik dalam beribadah kepada Allah. Termasuk dalam syirik ini adalah menyembelih tanpa menyebut nama Allah atau menyembelih dalam rangka berkurban untuk selain-Nya. Kedua, secara ijmâ' dapat menjadikan seseorang kafir adalah mengambil perantara yang dengannya seorang Muslim berdoa atau meminta syafaat kepada Allah. Ketiga, dinyatakan siapa saja yang tidak mengakui kekufuran orang-orang yang berperilaku di atas, maka orang yang ingkar tersebut juga telah menjadi kafir. ${ }^{41}$ Dengan kata lain, bagi siapa saja yang tidak membenarkan ajaran takfîr yang mereka yakini ini maka mereka juga-menurut kelompok Wahabi-telah dapat disebut kafir dan layak untuk diperangi. Keempat, apabila seorang Muslim meyakini bahwa ada ajaran lain yang lebih

38 Muḥammad b. 'Abd al-Wahhâb, al-Qawâ'id al-Arba'ah (Mekkah: Dâr Ibn 'Umar, 2003), 90 .

${ }^{39}$ Muḥammad b. 'Abd al-Wahhâb, Fadl al-Islâm (Mekkah: Dâr Ibn 'Umar, 2003), 108.

40 Said, Pengkafiran, 67.

41 Muḥammad b. 'Abd al-Wahhâb, Nawâqiẹ al-Islâm al-'Ashrah (Mekkah: Dâr Ibn 'Umar, 2003), 159. 
sempurna dan lebih baik bagi manusia daripada ajaran Rasul, maka mereka juga telah dapat dikatakan kafir. Termasuk dalam kaidah ini adalah bagi sebuah negara yang tidak menggunakan hukum Islam sebagaimana yang diaplikasikan Dinasti Su'ûd di wilayah kekuasaan mereka, mereka telah kafir. Seseorang juga dapat dikatakan kafir apabila membenci ajaran-ajaran yang telah dibawa oleh Nabi walaupun yang bersangkutan tersebut tetap mengamalkannya, apalagi jika dia mengejek dan merendahkannya. ${ }^{42}$ Kelima, nawâid al-Islâm lainnya adalah sihir, membantu orang-orang kafir dan juga apabila seseorang mempercayai ada seorang hamba yang bisa terbebas dari sharî‘ah yang dibawa oleh para utusan Allah, seperti Khidir yang banyak dipercayai telah terbebas dari kewajiban-kewajiban sharî̀ yang dibawa oleh Nabi Musa. Muslim yang meyakini hal tersebut menurut Wahabi telah kafir. ${ }^{43}$ Yang terakhir sekaligus mungkin paling sensitif adalah bahwa seorang Muslim yang tidak melaksanakan perintah-perintah Allah, seperti salat, puasa, zakat dan lain sebagainya juga dapat dikatakan telah kafir. ${ }^{44}$

Sumber ajaran dan pemikiran kaum Wahabi bisa ditemukan dalam beberapa karya, antara lain: a). Sittah Ușull 'Adhîmah yang membahas tentang konsep-konsep penting dalam Islam, termasuk tentang wajibnya taat kepada pemimpin; b). Faḍl al-Islâm yang membahas tentang kelebihan-kelebihan Islam serta konsep-konsepnya, dan juga tentang bid'ah; c). Thalathat al-Ușûl yang membahas tentang tiga pokok utama dalam beragama, yaitu pengetahuan tentang Allah, Rasul-Nya, dan tentang Islam; d). Kitâb al-Tawhị̂d al-ladhî Huwa Hạq Allâh 'alâ 'Abdì yang mengulas tentang Tauhid Ulûhîyah dan penjelasannya; e). al-Qawâ'id al-Arba'ah yang mengulas tentang syirik dan kewajiban memeranginya; f). Nawâqid al-Islâm yang menerangkan sepuluh hal yang dapat membatalkan keislaman seseorang; g). Masâil al-Jâhilîyah yang membahas tentang masalah-masalah yang dihadapi umat Islam sekarang ini, yang menyebabkan mereka tergolong dalam kelompok jahiliyah; dan h). Kashf al-Shububât yang mendiskusikan tentang kesempurnaan Islam dalam Rubûbîyah dan Ulûhîyah. ${ }^{45}$

\footnotetext{
42 Ibid., 160.

43 Ibid., 161.

44 Ibid., 161.

45 Majmû'ah al-A'immah al-Wahhâbîyah, Mutûn al-Tawhị̂d wa al-'Aqîdah (Mekkah: Dâr Ibn 'Umar, 2003), 351.
} 
Adapun konsep tentang takfir yang berimplikasi pada kehalalan darah seorang kafir, wajib diperangi dan diyakini akan kekal di neraka, ${ }^{46} \mathrm{Ibn}$ 'Abd al-Wahhâb berpendapat bahwa seseorang dikatakan beriman tidak cukup dengan hanya mengucapkan dua kalimat syahadat, tetapi harus dilengkapi dengan kewajiban-kewajiban yang lain seperti salat dan puasa. Melalaikan kewajiban-kewajiban tersebut dengan sengaja menurut mereka harus dihukumi sebagai kafir. Wahabi meletakkan amalan-amalan jawârị̣ sebagai bagian tidak terpisahkan dari akidah (keimanan) yang apabila ditinggalkan menjadikan yang bersangkutan dilabeli kafir dan tentu saja dalam batas tertentu-sebagaimana telah disebutkan di atasmenjadi halal darahnya dan kekal di neraka. Keyakinan inilah yang selanjutnya melegitimasi mereka dalam melakukan berbagai bentuk kekerasan atas nama pemurnian sharî'ah Islam. ${ }^{47}$

Salah satu contoh nyata, pada tahun 1802 M, dengan dukungan penuh dari Dinasti Su'ûd kelompok Wahabi menyerang Karbala, kota di mana terdapat kuburan Husayn b. 'Alî b. Abî Ṭâlib, yang sangat dipuja oleh golongan Shî‘ ah. Beberapa tahun kemudian mereka menyerang kota Madinah, kubah yang ada di atas kuburan-kuburan di sana mereka hancurkan, hiasan-hiasan yang ada di makam Nabi juga dirusak. Dari Madinah mereka teruskan penyerangan ke Makkah, kiswah sutra yang menutup Ka'bah juga dirusak, bahkan banyak yang meyakini bahwa mereka juga membunuh banyak umat Islam yang menghalangi 'perjuangan' mereka yang dalam kacamata ajaran Wahabi telah masuk dalam golongan orang-orang kafir yang boleh dibunuh. Ini semua mereka lakukan demi memberantas hal-hal yang mereka yakini sebagai bid'ah dan sumber kemusyrikan. ${ }^{48}$

\section{Pengaruh Berdirinya Kerajaan Arab Saudi Modern terhadap Tradisi Salat Berjemaah di Tanah Suci}

Munculnya empat maqâmât salat; Hanafî, Mâlikî, Shâfi'î dan Hanbalî di Masjidil Haram pada abad ke-10 tidak dapat dipisahkan dari sejarah munculnya dinasti Shî‘ah Fâtimîyah di Mesir yang berhasil memegang kendali atas daerah Hijaz (Mekah dan Madinah). Sejarah mencatat bahwa Shî'ah mulai berakar di Hijaz pada masa Fâtimîyah ini. Berbarengan

\footnotetext{
46 Said, Pengkafiran Sesama, 67.

${ }^{47}$ Hamim, Islam dan NU, 222-223.

${ }^{48}$ Hitti, History, 948.
} 
dengan bermulanya kekuasaan Dinasti Fâtimîyah di Hijaz ini pula, Nižâm al-Ashrâf (sistem pemerintahan para Sharîf, keturunan Hasan b. 'Alî b. Abî Tâlib) mulai menancapkan kekuasaannya di Hijaz. Semenjak itu, ajaran Shî‘ah mulai tersebar di wilayah Haramayn tersebut, selain aliran Sunnah yang sudah mengakar kuat sejak lama. ${ }^{49}$

Akar permasalahan yang mengakibatkan terbentuknya maqâmat salat di Masjidil Haram dan Masjid Nabawi memang tidak dapat dilepaskan dengan situasi politik aliran pada saat itu. Sebagai penguasa Mekah dan Madinah yang menganut aliran Shî'ah Zaydîyah, ${ }^{50}$ penguasa Fâțimîyah tentu menginginkan untuk dapat mendirikan salat jemaah di Masjidil Haram dan Masjid Nabawi menurut mazhab yang mereka anut. ${ }^{51}$

Akan tetapi, tidaklah mungkin bagi dinasti Fâtimîyah untuk membatalkan salat jemaah menurut mazhab Sunnî dan menggantikannya dengan mazhab Shî‘ah di Masjidil Haram dan di Masjid Nabawi, karena aliran Sunnî telah dianut oleh mayoritas penduduk setempat sejak sebelum mereka datang. ${ }^{52}$ Oleh karena itu, pemerintah Fâțimîyah akhirnya menerapkan berbilangnya salat jemaah di Masjidil Haram dan Masjid Nabawi, yaitu salat jemaah menurut mazhab-mazhab Sunnî yang memiliki pengikut yang besar (Shâfíî, Hanafî, dan Mâlikî), ditambah dengan mazhab Shî‘ah Zaydîyah, mazhab yang dianut penguasa ketika itu. Inilah awal mula sejarah terbentuknya maqâmat salat di al-Haramayn. ${ }^{53}$ Setelah pengaruh Shî‘ah mulai memudar, mị̆rab mereka akhirnya dihapuskan dan digantikan dengan miḩrab mazhab Hanbalî. Sedangkan mị̣rab tiga mazhab Sunnî lainnya, yaitu Shâfíî, Ḥanafî dan Mâliki tetap dipertahankan. ${ }^{54}$

Tidak banyak diketahui tentang tertib salat di Masjidil Haram pada masa Fâțimîyah. Namun, pada masa Mamâlik, paling tidak sampai masa al-Fâsî̀ (1373-1428 M), diketahui bahwa mereka menunaikan salat empat kali secara bergantian. Yang pertama adalah salat jemaah mazhab Shâfi'î kemudian mazhab Ḥanafî, lalu mazhab Mâlikî, dan terakhir mazhab

\footnotetext{
49 al-Sibâcî, Târîkh Mekah, Vol. 1, 214.

${ }^{50}$ Hitti, History, 787.

51 Yatim, Sejarah Sosial, 61.

52 Ibid., 61.

53 Ibid., 61.

${ }^{54}$ Ibid., 62.
} 
Hanbali. ${ }^{55}$ Ini semua terjadi pada salat-salat selain Maghrib. Karena di waktu salat Maghrib dilaksanakan, mereka salat pada waktu yang sama. Hal itu disebabkan karena waktu Maghrib sangat singkat, sehingga tidak mungkin dilakukan secara bergantian. Akibatnya, orang-orang yang sedang menunaikan salat merasa terganggu oleh ketidakjelasan karena bercampurnya suara-suara imam dan bilal dan juga perbedaan gerak orang-orang yang salat. ${ }^{56}$

Ketika Dinasti Su'ûd I berhasil menganeksi Hijaz, tepatnya pada tahun 1803 M, yaitu ketika Dinasti Su'ûd untuk pertama kalinya berhasil menguasai kota Mekah, Sa'ûd b. 'Abd al-'Azîz dengan tegas mengeluarkan perintah untuk menghapus tradisi berbilangnya salat berjemaah yang sudah berlangsung selama beberapa abad tersebut. Dia menganjurkan agar di Masjidil Haram hanya dilakukan satu kali salat berjemaah dengan satu imam saja untuk setiap waktu. Salat Subuh dipimpin oleh imam mazhab Shâfi'î, Dzuhur oleh imam mazhab Mâlikî, dan seterusnya. Adapun salat Jumat diimami oleh Mufti Mekah, 'Abd alMâlik al-Qal'î al-Hanafî, qâdî yang ditetapkan dari Istanbul. ${ }^{57}$

Menanggapi kebijakan penguasa baru Dinasti Su'ûd tersebut, para ulama nampaknya tidak keberatan dengan hanya diselenggarakannya satu salat jemaah di Masjidil Haram. Bahkan sebenarnya kritik terhadap berbilangnya salat berjemaah di Masjidil Haram itu sudah banyak dilontarkan Ulama dari beberapa negeri Muslim lainnya. Apalagi, pada abad ke-18 banyak Ulama terkemuka Hijaz yang menekankan rekonsiliasi di antara keempat mazhab fiqh. Artinya, meskipun tetap mempertahankan kepatuhan pada satu mazhab tertentu, pada saat yang bersamaan mereka harus mengampanyekan toleransi terhadap pendapat-pendapat mazhab lain yang bisa jadi berbeda atau malah mungkin bertentangan. ${ }^{58}$

Ketika Ali Pasha berhasil mengambil alih kekuasan Dinasti Su'ûd awal abad ke-19, kembali tejadi perubahan dalam tradisi salat berjemaah. Salat jemaah yang berbilang di Masjidil Haram dan Masjid Nabawi kembali muncul setelah sebelumnya sempat dihapuskan oleh Dinasti Su'ûd. Hanya saja, saat itu umat Islam lebih sadar bahwa ajaran sharî‘ah

\footnotetext{
55 Ibid., 62.

56 Ibid., 63.

${ }^{57}$ Ibid., 170.

58 Ibid., 171.
} 
Islam sebenarnya memperkenankan kaum Muslimin menunaikan salat jemaah di belakang seorang imam yang berbeda mazhab dengannya. ${ }^{59}$

Kalau kemudian di Masjidil Haram kembali dilaksanakan salat jemaah menurut empat mazhab Sunnî, hal tersebut bukanlah karena latar belakang perbedaan mazhab dalam sharî‘ah Islam, namun lebih karena menurut mereka bahwa kota Mekah dan Madinah adalah kota suci milik seluruh umat Islam. Mekah bukan hanya milik penduduknya, bukan pula milik dinasti tertentu di sana, sehingga keberadaan mazhab-mazhab tersebut tidak mungkin diabaikan. ${ }^{60}$

Namun walaupun begitu, mazhab Hanafî yang merupakan mazhab resmi pemerintah Turki Uthmânî dan mazhab Shâfi'î yang merupakan mazhab mayoritas penduduk Mekah, memiliki kelebihan tertentu dalam beberapa hal.

Kecuali mengembalikan suasana kehidupan beragama di Hijaz sebagaimana sebelum masa Dinasti Su'ûd, kehadiran kekuasaan Ali Pasha di Hijaz tidak banyak membawa pengaruh keagamaan. Hal ini sungguh wajar mengingat pembaruan Ali Pasha tidak berhubungan secara langsung dengan ajaran keagamaan Islam. Bukan saja karena dia berusaha membebaskan diri dari kekuatan yang berada di tangan para ulama, tetapi juga karena sampai tahun 1833 M Hijaz dalam kehidupan beragama lebih berada di bawah pengaruh Turki Uthmânî. Di samping itu, memang Ali Pasha tidak memiliki perhatian besar terhadap lembaga keagamaan, kalau bukan justru ingin menekannya karena dipandang dapat merongrong pembaruan. Apalagi, kekuasan mutlaknya di Hijaz hanya berlangsung singkat.

Pada awal abad ke-20, ketika Ibn Sa'ûd dapat kembali menguasai wilayah Hijaz, dan memproklamirkan dirinya sebagai Imâm (pemimpin) orang-orang Wahabi, sekaligus menghidupkan kembali kerajaan Saudi yang dulu sempat menguasai Hijaz. ${ }^{61}$ Saat itu itu pula, kebijakan pemurnian tauhid dan gerakan ortodoksi sharî‘ah Islam kembali gencar dilakukan oleh kerajaan Saudi Arabia modern ini. Termasuk di antara kebijakan kerajaan adalah menghapuskan kembali salat jemaah yang berbilang di Masjidil Haram. Tidak dapat dipungkiri bahwa berdirinya kerajaan Arab Saudi modern memiliki pengaruh yang besar terhadap

\footnotetext{
59 Ibid., 286.

60 Ibid., 287.

${ }^{61}$ Hunter (ed.), The Politics, 104-105.
} 
tradisi keagamaan di Hijaz. Hal ini karena kerajaan turut aktif dalam mengontrol akidah dan perilaku keberagamaan seluruh penduduknya secara ketat. ${ }^{62}$

Selanjutnya, kerajaan mengangkat imam-imam masjid yang beraliran Wahabi sekaligus menjadikan aliran tersebut sebagai mazhab resmi kerajaan. Seluruh kegiatan dakwah dan keagamaan juga diatur oleh kerajaan, di bawah badan tertentu yang ditunjuk raja untuk mengatur kegiatan keberagamaan penduduknya. Badan resmi negara tersebut memiliki hak mutlak dalam memberikan lisensi kepada para imam salat di Masjidil Haram dan masjid Nabawi sekaligus mengangkat dan memberhentikan mereka. Selain itu, kerajaan juga mengontrol secara ketat materi-materi khotbah salat Jumat di Haramayn dan masjid-masjid lain di Arab Saudi agar sesuai dengan ajaran Wahabi serta tidak membahayakan kepentingan politik penguasa. ${ }^{63}$

\section{Pengaruh Politik Hijaz terhadap Perkembangan Lembaga Pendidikan Islam}

Sebagaimana yang telah dijelaskan sebelumnya bahwa sebelum berdirinya sekolah-sekolah modern, lembaga pendidikan di Hijaz terdiri atas dua jenjang, yaitu al-Ta 'lim al-Awwalî (lembaga pendidikan dasar) dan al-Ta'lìm al-'Alı̀ (lembaga pendidikan tinggi). Al-Ta'lìm al-Awwalî adalah proses belajar mengajar yang berlangsung di Kuttâb. ${ }^{64}$

Kuttâb sendiri adalah tempat proses belajar-mengajar yang biasa berlangsung di masjid-masjid atau di rumah seseorang yang dianggap lebih terpelajar untuk kemudian mereka mengajarkan ilmunya, dengan harapan mendapat pahala dari Allah atau sedikit imbalan berupa harta benda dari para dermawan yang memiliki perhatian dalam perkembangan pendidikan Islam di Hijaz. ${ }^{65}$ Sedangkan al-Ta'lîm al-'Âlî (lembaga pendidikan tinggi) adalah proses belajar mengajar bagi orang yang ingin melanjutkan studinya setelah menamatkan proses belajar mengajar di kuttâb. Al-Ta'lìm al-Âlî ini biasanya berlangsung di Masjidil Haram dan Masjid Nabawi di kota Madinah yang dapat dipandang sebagai perguruan

\footnotetext{
${ }^{62}$ Mufrodi, Islam di Kawasan, 157.

63 Ibid., 158.

${ }^{64}$ Yatim, Sejarah Sosial, 205.

65 Dewan Redaksi Ensiklopedi Islam, Ensiklopedi Islam, Vol. 3 (Jakarta: Ichtiar Baru Van Hoeve, 1997), 86.
} 
tinggi dalam tingkat pendidikannya, setara dengan yang dimiliki oleh Universitas al-Azhar Mesir.

Di beberapa ḥalâqah ilmiah Masjidil Haram dan Masjid Nabawi diberikan pelajaran yang lebih tinggi, yaitu ilmu-ilmu keagamaan Islam, bahasa Arab, Târikh (sejarah), Tarâjim (biografi tokoh-tokoh), al-Riyâdiyyât (matematika/ilmu hitung), al-Mantiq (logika), dan al-Farâid (ilmu waris). ${ }^{66}$ Karena banyaknya jumlah ḥalâqa ketika itu, yang pengajarannya terus berlangsung dari setelah salat Subuh hingga selepas Isya, maka para penuntut ilmu diberi kebebasan untuk memilih ḥalâah ilmiah yang diminatinya, sesuai dengan ilmu pengetahuan yang ingin diperdalamnya. Pengajaran yang berlangsung di dua masjid suci tersebut memang banyak diyakini memiliki kualitas dan kurikulum yang setara dengan yang terdapat di Universitas al-Azhar Mesir. ${ }^{67}$

\section{Kondisi Pendidikan Hijaz masa Dinasti Su'ûd I}

Pada masa Dinasti Su'ûd I, proses belajar-mengajar di ḥalâqâh ilmiah di Masjidil Haram dan Masjidil Nabawi terus berlangsung, namun berada di bawah kendali penuh negara melalui Shaykh al-Ḥaram. Berbagai ḥalâqah fiqh tetap berlangsung seperti sebelumnya, mengajarkan empat mazhab fiqh Sunnî. Hanya saja, sesuai dengan ajaran yang dianutnya, penguasa Dinasti Su'ûd I memerintahkan agar kitab Kashf al-Shubhât, yaitu sebuah kitab yang ditulis oleh dan berisi ajaran-ajaran Ibn 'Abd al-Wahhâb, untuk diajarkan sebagai materi wajib di seluruh ḥalâqah umum yang dihadiri oleh para ulama dan penduduk. Namun kemudian, ḥalâqah itu kembali seperti sebelumnya setelah Dinasti Su'ûd I berakhir di Hijaz akibat dari serangan Ali Pasha. Di sisi lain, pengajaran tasawuf nampak mengalami sedikit perubahan, karena tarekat ortodoksi yang semakin kuat. ${ }^{68}$

Selama masa Dinasti Su'ûd I—kecuali memerintahkan pembelajaran beberapa kitab di Masjidil Haram dan Masjid Nabawi, yaitu kitab-kitab yang sejalan dengan gagasan reformasinya seperti yang telah disebutkan di atas-Dinasti Su'ûd I tidak banyak melakukan pembaruan dalam bidang pendidikan. Bahkan dapat dikatakan bahwa lembaga pendidikan

\footnotetext{
66 al-Sibâî̀, Târîkh Mekah, Vol. 2, 580.

${ }^{67}$ Yatim, Sejarah Sosial, 287.

68 Ibid., 194.
} 
di Mekah dan Madinah pada masa pendudukan Dinasti Su'ûd I ini, mengalami kemunduran dibandingkan masa-masa sebelumnya.

Pada paruh kedua abad ke-19 M, yaitu setelah Dinasti Su'ûd I dapat ditaklukkan oleh Ali Pasha. Hijaz menjadi saksi munculnya lembaga pendidikan modern. Masuknya lembaga pendidikan di Hijaz didahului oleh sekolah-sekolah modern Turki. Akan tetapi, karena masa masuknya itu sejalan dengan berkembangnya gagasan nasionalisme Turki, sekolahsekolah modern yang didirikan pemerintahan di Hijaz tidak mengalami perkembangan pesat, karena bahasa pengantar yang digunakan di sana adalah bahasa Turki sehingga penduduk kurang mendukung dan berpartisipasi. ${ }^{69}$

Walau bagaimanapun sekolah-sekolah modern Turki itu tetap memberi ilham bagi penduduk setempat untuk mendirikan lembaga pendidikan modern yang menggunakan bahasa Arab sebagai bahasa pengantarnya. Dalam pendirian sekolah-sekolah modern terakhir ini, Mekah banyak berhutang budi kepada ulama-ulama India. Kekuatan ekonomi penduduk Muslim asal India yang juga mendapat dukungan dari dermawan-dermawan kaya India membuat sekolah-sekolah modern yang mereka dirikan mampu mengembangkan eksistensinya.

Memang sekolah swasta di Mekah berdiri lebih dahulu dibandingkan dengan sekolah-sekolah swasta modern di kota lain di Hijaz, bahkan dibandingkan dengan sekolah modern yang didirikan oleh pemerintah Turki 'Uthmânî sekalipun. Contoh nyata dalam kasus ini adalah sekolah al-Șawlatîyah di Mekah. Kalau sekolah al-Rashîdîyah yang didirikan oleh pemerintah Turki 'Uthmânî pertama kali didirikan pada tahun 1884 M, maka sekolah swasta al-Ṣawlatîyah telah berdiri sebelum itu. ${ }^{70}$

Riwayat berdirinya sekolah ini bermula dari datangnya seorang tokoh Ulama pejuang asal India yang melawan penjajahan Inggris, yaitu Shaykh Muhạmmad Raḥmat Allâh al-'Uthmânî al-Hindî pengarang Kitab İ̧hâr al-Haq fî̀ al-Difâ' 'an al-Dîn al-Islâmî. Dia merencanakan mendirikan sekolah untuk pengajaran agama, bahasa Arab dan al-Qur'ân. Rencananya itu didengar oleh seorang wanita dermawan yang kaya asal India bernama Șawlat al-Nisâ' yang kemudian membantunya. Oleh

${ }^{69}$ Hasan Hayali, Arabs and Young Turks: Ottomanism, Arabism, and Islamism in The Ottoman Empire 1908-1918 (London: University of California Press, 1997), 146.

70 Rashid Khalidi, dkk (ed.), The Origins of Arabs Nationalism (New York: Columbia University Press, 1991), 198. 
karena itu, sekolahnya tersebut dinamakan al-Madrasah al-Ṣawlatîyah. Ini terjadi pada tahun $1873 \mathrm{M}^{71}$

\section{Kondisi Pendidikan Hijaz pada Awal Berdirinya Kerajaan Arab Saudi Modern}

Pada awal abad ke-20, ketika Ibn Sa'ûd dapat kembali menguasai wilayah Hijaz sekaligus mendirikan kerajaan Arab Saudi Modern, hal pertama yang Ibn Sa'ûd prioritaskan adalah menciptakan keamanan umum di Jazirah Arab. Ia dengan sangat baik dapat menyelesaikan persoalan-persoalan keamanan negerinya dengan hukuman-hukuman tertentu yang keras. Bahkan dapat dikatakan, Ibn Sa'ûd sama sekali tidak memperlihatkan pandangan luas dan kepemimpinan yang mengesankan sebagaimana yang diharapkan. ${ }^{72}$

Dalam bidang pendidikan, Ibn Sa'ûd mulai mengirimkan beberapa pemudanya ke luar negeri untuk belajar dalam bidang ilmu kedokteran dan telegrafi, tetapi ia tidak menyediakan lembaga pendidikan modern bagi warganya secara umum, padahal mayoritas penduduk Arab Saudi ketika itu banyak sekali yang masih buta aksara. Di Hijaz kala itu memang kondisi pendidikan para penduduknya sangat memprihatinkan. Para penuntut ilmu di Masjidil Haram dan Masjid Nabawi didominasi oleh penduduk dari luar Hijaz dan para mujâwirûn. ${ }^{73}$

Tidak jauh berbeda dengan Hijaz, di Riyad juga memiliki kondisi pendidikan yang buruk, bahkan lebih menyedihkan dari Hijaz. Kota tempat istana Ibn Sa 'ûd kokoh berdiri ini pada tahun 1922 M tercatat belum ada sekolah resmi sama sekali. Anak-anak dan para keponakan Ibn Sa 'ûd sendiri belajar membaca al-Qur'ân secara bersama-sama di sebuah ruang yang sangat sederhana, di bawah bimbingan seorang ulama. Menghafal adalah unsur utama dalam pelajaran tradisional di sana. Seluruh kemampuan belajar disediakan hanya untuk mempelajari alQur'ân. Seluruh daya kreasi anak-anak diarahkan untuk mempertajam kemampuan menghafalkan apa yang telah dibacanya. Keadaan ini jelas menundukkan bahwa pendidikan di Riyad pada masa itu jauh berada di belakang dibandingkan dengan yang terjadi di Hijaz. ${ }^{74}$

\footnotetext{
71 al-Sibâû̂, Târîkh Mekah, 581.

72 Yatim, Sejarah Sosial, 229.

${ }^{73}$ Robert Lacey, Kerajaan Petrodolar Saudi Arabia (Jakarta: Pustaka Jaya, 1986), 224.

${ }^{74}$ Ibid., 225.
} 
Terlepas dari ini semua, yang jelas seluruh institusi pendidikan, baik formal maupun non-formal, masuk dalam pengawasan sangat ketat pemerintah Arab Saudi. Kurikulum pendidikan yang diajarkan harus sesuai dengan semangat ortodoksi dan pemurnian akidah ala Wahabi. Proses penyebaran paham Wahabi melalui gerakan pendidikan tersebut terus berlangsung hingga dewasa ini. ${ }^{75}$

\section{Relasi antara Sharî‘ah dan Tasawuf}

Pada akhir abad ke-18 kehidupan tarekat di Hijaz berjalan di antara dua persimpangan jalan, yaitu antara yang cenderung kepada ortodoksi sebagai pengaruh dari ajaran Ibn Taymîyah, maupun yang cenderung kepada tasawuf populer. Proses itu terjadi selama satu dekade, yaitu ketika Hijaz berada di bawah kekuatan politik Dinasti Su'ûd I, 1803-1813 M. Saat itu perkembangan sharî'ah diintervensi penuh oleh negara dengan kekuatan politik. Pandangan Dinasti Su'ûd dalam bidang tasawuf dan sharî‘ah, oleh Fazlur Rahman, digolongkan sebagai golongan ortodoksi paling kanan yang identik dengan kelompok Abl al-Hadìth. Golongan ini sangat curiga dan antipati terhadap tasawuf. ${ }^{76}$ Dari sinilah ortodoksi yang dipelopori oleh pembaruan neo-sufisme terus menguat. Gerakan ortodoksi ini mendapat dukungan penuh dari Dinasti Su'ûd yang menganut aliran Wahabi. ${ }^{77}$

Gerakan yang dipelopori Ibn 'Abd al-Wahhâb ini juga biasa disebut sebagai gerakan revivalis, yaitu pembaruan yang muncul pada masa pramodern yang memilih suatu jalan radikal untuk mempersoalkan kembali tradisi-tradisi yang sudah menyebar dalam diri umat Islam atas dasar sumber-sumber asli Islam, yaitu al-Qur'ân dan Sunnah Nabi. ${ }^{78}$

Sebagai gerakan revivalisme pra-modernis, gerakan Wahabi menyeru untuk kembali kepada sumber asli agama Islam, yaitu al-Qur'ân dan Hadîth, serta meninggalkan apa yang mereka anggap takhayul dalam bentuk praktik-praktik tasawuf populer dan tradisi yng tidak sejalan

\footnotetext{
${ }^{75}$ Hamim, Islam dan NU, 222-223.

76 Fazlur Rahman, Islam, terj. Ahsin Muhammad (Bandung: Penerbit Pustaka, 2010), 291.

77 Ibid., 292.

78 M. Hasbi Amiruddin, Konsep Negara Islam Menurut Fąlur Rahman (Yogyakarta: UII Press, 2006), 17.
} 
dengan ajaran Wahabi. Gagasan pemurniaan itu oleh Dinasti Su'ûd dilaksanakan dan disebarluaskan dengan kekuatan politik. ${ }^{79}$

Dengan demikian, Dinasti Su'ûd I telah menjelma menjadi sebuah kekuatan politik pemaksa bagi berlakunya ajaran-ajaran Wahabi di Hijaz. Selama 1803-1813 M, Hijaz dibersihkan oleh Dinasti Su'ûd I dari adat istiadat penduduk yang bertentangan dengan ajaran Wahabi, dan segala sesuatu yang-menurut pandangan gerakan revivalis ini-dapat menjerumuskan umat Islam ke dalam praktik-praktik tasawuf populer yang mereka nilai sudah sangat menyimpang dari ajaran Islam yang benar. Tidak ada penduduk yang terlepas dari kontrol penguasa Dinasti Su'ûd I dalam kehidupan beragama mereka. Penguasa berusaha memurnikan kehidupan beragama seluruh penduduk, termasuk kabilahkabilah Arab Nomad, yang sebelumnya nyaris dapat dikatakan berada di luar sistem hukum negara dan tidak tersentuh lembaga pendidikan sama sekali. $^{80}$

Meskipun warna politik Dinasti Su'ûd berhasil ditindas oleh Ali Pasha, namun perkembangan ajaran revivalisme Wahabi tetap tidak terbendung. Neo-sufisme semakin kuat, karena pada masa kekuasaan Ali Pasha di Hijaz banyak ulama Mesir yang berimigrasi ke sana. Mereka kebanyakan dikenal sebagai ulama yang berpegang teguh terhadap sharî‘ $a h$ Islam. ${ }^{81}$

Di samping itu, menguatnya ortodoksi juga disebabkan oleh banyaknya ulama Mujâwirûn yang sudah terpengaruh oleh gagasan revivalisme dan modernisme di negeri mereka masing-masing, yang semuanya memandang negatif terhadap tasawuf populer dan menghimbau untuk kembali kepada sumber asli agama Islam, al-Qur'ân dan Hadîth Nabi. Di Hijaz mereka mengajar di sekolah-sekolah modern dan di ḥalâqah-ḥalâqab Masjidil Haram dan Masjid Nabawi dengan memperkenalkan gagasan revivalisme dan modernisme Islam itu. ${ }^{82}$

Menguatnya ortdoksi itu tidak hanya terlihat pada komunitas ilmiah, para guru dan penuntut ilmu, tetapi juga pada sebagian bumi putra Hijaz dari kalangan Arab Badui. Kalangan Arab kabilah di Hijaz baik sebelum

\footnotetext{
79 Albert Hourani, A History of the Arab Peoples (Cambridge: Harvard University Press, 1991), 258.

${ }^{80}$ Hamim, Islam dan NU, 223.

81 Yatim, Sejarah Sosial, 288.

82 Ibid., 289.
} 
maupun pada masa pendudukan Dinasti Su'ûd I banyak yang menjadi pengikut Wahabi, dan pada masa sesudahnya mereka menjadi anggota persaudaraan tarekat al-Sanûsîyah yang-sejalan dengan ajaran Wahabimenghimbau untuk kembali kepada ajaran Islam yang murni. ${ }^{83}$

Setelah Ibn Sa'ûd sempurna mendirikan Kerajaan Arab Saudi Modern pada abad ke-20, gerakan ortodoksi untuk kembali kepada sharî‘ah Islam yang bersumber dari al-Qur'ân dan Hadîth semakin diperkuat. Gerakan ini dipercepat dengan didirikannya sekolah-sekolah modern yang kurikulum pendidikannya sejalan dengan ide dan gagasan pemurnian akidah Ibn 'Abd al-Wahhâb. Sekolah-sekolah modern tersebut ikut berperan sedikit demi sedikit dalam menggeser bentukbentuk tasawuf zaman pertengahan yang sempat menguasai Hijaz. ${ }^{84}$

\section{Catatan Akhir}

Dari kacamata sosial keagamaan, paling tidak ada empat tradisi keagamaan yang ikut terpengaruh akibat dari dinamika politik Semenanjung Arab tersebut, yaitu: pertama, dalam bidang pemurnian tauhid; Kedua, tradisi pelaksanaan salat berjemaah di Tanah Suci; Ketiga, perkembangan pendidikan, dan; Keempat, hubungan antara sharî́ah dan tasawuf.

Dengan berdirinya Kerajaan Saudi Modern, Hijaz kembali dibersihkan dari praktik-praktik takhayul, khurafât, tarekat populer, dan tradisi keagamaan penduduk yang menurut mereka telah menyimpang dari ajaran agama yang benar. Sebagaimana pada masa Dinasti Su'ûd I, gerakan purifikasi sharî‘ah ini melibatkan intervensi langsung dari pemerintah Arab Saudi. Kerajaan mengontrol dengan ketat seluruh aktivitas keagamaan penduduknya agar tetap sejalan dengan pandangan Wahabi. Tidak mengherankan bila doktrin Wahabi ini memiliki karakter militan dan ekstrem, karena memang gerakannya bertumpu pada kekuatan militer penguasa.

Dalam bidang pendidikan, Dinasti Su'ûd I tidak banyak melakukan pembaruan dalam bidang pendidikan. Sedangkan pada awal Kerajaan Arab Saudi Modern, Ibn Sa'ûd sudah mulai mengirimkan beberapa pemudanya ke luar negeri untuk belajar ilmu-ilmu modern walaupun kebijakan ini tidak ditunjang dengan lembaga-lembaga pendidikan modern bagi warga Arab Saudi sendiri yang mayoritas masih buta aksara.

${ }^{83}$ Rahman, Islam, 292.

84 Ibid., 301-302. 
Saat itu di Hijaz kondisi pendidikannya masih sangat memprihatinkan. Dalam bidang sharî‘ ah dan tasawuf, kelompok Wahabi telah menjelma menjadi sebuah gerakan revivalisme pra-modernis yang menyeru untuk kembali kepada sumber asli agama Islam, yaitu al-Qur'ân dan Hadîth, serta meninggalkan praktik-pratik tasawuf populer dan tradisi yang tidak sejalan dengan ajaran mereka. Fenomena ini menandai digesernya tradisi tasawuf populer di Hijaz oleh gerakan neo-sufisme yang radikal dan ortodoks.

\section{Daftar Rujukan}

Ali, Mukti. Alam Pikiran Islam Modern di Timur Tengah. Jakarta: Djambatan, 1995.

Amiruddin, M. Hasbi. Konsep Negara Islam Menurut Fazlur Rabman. Yogyakarta: UII Press, 2006.

Armanions, Fabe. "The Islamic Traditions of Wahhabism and Salafiyya", dalam CRS Report for Congress, www.fas.org/sgp/crs/misc/RS21695.pdf. 20 Maret 2013.

Azra, Azyumardi. Jaringan Ulama Timur Tengah dan Kepulauan Nusantara Abad XVII dan XVIII. Jakarta: Prenada Media, 2004.

----. Renaisans Islam Asia Tenggara: Sejarah Wacana dan Kekuasaan. Bandung: Remaja Rosdakarya, 2000.

Badrie, Muhamamd Thahir. Syarah Kitab al-Taubid Muhammad bin Abdul Wahab. Jakarta: Pustaka Panjimas, 1987.

Chalik, Abdul. Islam dan Kekuasaan: Dinamika Politik dan Perebutan dalam Ruang Negara. Yogyakarta: Interpena, 2012.

Dallal, Ahmad. "The Origins and Objectives of Islamic Revivalist Thought (1750-1850)", Journal of the American Oriental Society, Vol. 113. No. 3, Juli-September 1993.

Dewan Redaksi Ensiklopedi Islam, Ensiklopedi Islam, Vol. 3. Jakarta: Ichtiar Baru Van Hoeve, 1997.

Hamim, Thoha. Islam dan NU di Bawah Tekanan Problematika Kontemporer: Dialektika Kehidupan Politik, Agama, Pendidikan dan Sosial Masyarakat Muslim. Surabaya: Diantama, 2004.

Hayali, Hasan. Arabs and Young Turks: Ottomanism, Arabism, and Islamism in The Ottoman Empire 1908-1918. London: University of California Press, 1997.

Hitti, Philip K. History of The Arabs: From the Earliest Times to the Present, terj. Cecep Lukman Yasin, dkk. Jakarta: Serambi Ilmu, 2010. 
Hourani, Albert. A History of the Arab Peoples. Cambridge: Harvard University Press, 1991.

Kamil, Sukran. Pemikiran Islam Tematik: Agama dan Negara, Demokrasi, Civil Society, Syariah dan HAM, Fundamentalisme, dan Antikorupsi. Jakarta: Kencana, 2013.

Khalidi, Rashid dkk (ed.). The Origins of Arabs Nationalism. New York: Columbia University Press, 1991.

Lacey, Robert. Kerajaan Petrodolar Saudi Arabia. Jakarta: Pustaka Jaya, 1986.

Lapidus, Ira M. A History of Islamic Societies. Cambridge: Cambridge University, 1989.

Maḥrân, Muḥammad Bayyûmî. Dirâsâtfî Târikh al-'Arab al-Qadîm. Riyad: al-Matâbi‘ al-Ahlîyah, 1997.

Maqdisî (al), Abû Muḥammad 'Ậ̦im. al-Kawâshif al-Jalîyah fî̀ Kufr alDawlah al-Su'ûdiyah. Riyad: Muassasat al-Rafid, t.th.

Martin, Richard C. Pendekatan Kajian Islam dalam Studi Agama, terj. Zakiyuddin Baidhawy. Surakarta: Muhammadiyah University Press, 2002.

Mufrodi, Ali. Islam di Kawasan Kebudayaan Arab. Surabaya: Anika Bahagia, 2010.

-----. Pranata Sosial Islam di Indonesia 1900-1942: Politik dan Pendidikan. Surabaya: Alpha, 2007.

Noer, Deliar. Gerakan Modern Islam di Indonesia 1900-1942. Jakarta: LP3ES, 1980.

Rahman, Fazlur. Islam, terj. Ahsin Muhammad. Bandung: Penerbit Pustaka, 2010.

-----. Major Themes of the Qur'an. Chicago: Bibliotheca Islamica, 1980.

Said, Imam Ghazali. Pengkafiran Sesama Muslim Menurut Abu Hamid alGhazali. Surabaya: Diantama, 2012.

Sibâ'î (al), Aḥmad. Târîkh Mekah. Mekah: Maktabah al-Ṣafâ, 1420.

Sindi, Abdullah Mohammad. "Britain and the Rise of Wahhabism and the House of Saud", dalam Kana'an Bulletin, www.kanaanonline .org/20 Maret 2013.

Sopyan, Yayan. Tarikh Tasyri': Sejarah Pembentukan Hukum Islam. Depok: Gramata Publishing, 2010.

Sunanto, Musyrifah. Sejarah Peradaban Islam Indonesia. Jakarta: Raja Grafindo Persada, 2012. 
Wahhâb (al), Muhammad b. 'Abd. al-Qawâ'id al-Arba'ah. Mekkah: Dâr Ibn 'Umar, 2003.

----. Fadl al-Islâm. Mekkah: Dâr Ibn 'Umar, 2003.

----. Kashf al-Shubuhât. Mekkah: Dâr Ibn 'Umar, 2003.

----. Nawâqid al-Islâm al-'Ashrah. Mekkah: Dâr Ibn 'Umar, 2003.

----. Sittah Ușûl 'Adhîmah. Mekkah: Dâr Ibn 'Umar, 2003.

-----. Thalâthat al-Usû́l. Mekkah: Dâr Ibn 'Umar, 2003.

Wahhâbîyah (al), Majmû'ah al-A'immah. Mutûn al-Tawhî̀ wa al-'Aqîdah. Mekkah: Dâr Ibn 'Umar, 2003.

Yatim, Badri. Sejarah Sosial Keagamaan Tanah Suci: Hijaz (Mekah dan Madinab) 1800-1925. Jakarta: Logos Wacana Ilmu, 1999. 